\title{
Dampak Kenakalan Remaja Untuk Meningkatkan Kesadaran Dari Bahaya Kenakalan Remaja Bagi Masa Depan
}

\author{
Sulastri $^{\text {a,1 }}$, Eti hayati ${ }^{\mathrm{b}, 2}$, Aulia Nursyifa ${ }^{\mathrm{c}, 3}$ * \\ a,b,c Fakultas Keguruan dan Ilmu Pendidikan, Universitas Pamulang* \\ ${ }^{1}$ dosen02081@unpam.ac.id, ${ }^{2}$ dosen01391@unpam.ac.id, ${ }^{3}$ aulianursyifa@unpam.ac.id \\ *Korespodensi Penulis
}

Naskah diterima: 1 Maret 2020, direvisi: 12 Maret 2020, disetujui: 25 Maret 2020

\begin{abstract}
Abstrak
Para remaja kerap kali melakukan kenakalan yang dapat melanggar aturan, dalam melakukan perbuatan yang nakal para remaja belum memiliki kesadaran akan dampak kenakalan yang dilakukan yang dapat mengancam masa depannya. Oleh karena itu, diperlukan upaya penyuluhan tentang dampak kenakalan remaja dengan tujuan untuk meningkatkan kesadaran remaja terhadap bahaya kenakalan remaja. Metode kegiatan pengabdian kepada masyarakat dilakukan dengan cara memberikan penyuluhan kepada remaja di Pulau Untung Jawa. Hasil pengabdian menunjukkan bahwa adanya peningkatan kesadaran remaja tentang bahaya kenakalan remaja yang dapat merusak masa depannya, selama kegiatan ini para remaja cukup antusias dalam melakukan konsultasi terhadap masalah yang ada dalam dirinya sehingga dengan adanya keterbukaan membuat remaja dapat melewati permasalahan dalam dirinya tanpa melakukan perilaku nakal yang dapat merusak dirinya. Maka dari itu perlu adanya kerjasama semua pihak untuk mencegah masalah kenakalan remaja meliputi orangtua, sekolah, dan masyarakat.
\end{abstract}

Kata-kata kunci: Dampak ; Kenakalan Remaja ; Kesadaran;

\begin{abstract}
Teenagers often do mischief that can violate the rules, in doing naughty deeds the youth do not have awareness of the impact of the mischief that can threaten his future. Therefore, an outreach effort was needed about the impact of juvenile delinquency with the intention of raising adolescent awareness of the dangers of juvenile delinquency. The method of community devotion activities is done by giving counseling to the youth in Pulau Untung java. The results showed that there was an increase in adolescents ' awareness of the dangers of adolescent delinquency that could ruin his future, during this activity the youth were enthusiastic in consulting the problem that existed within him so that with the openness of making the youth could pass the problem in him without committing mischievous behavior that could ruin him. Therefore, it is necessary to cooperate with all parties to prevent the problems of juvenile delinquency including parents, schools, and communities.
\end{abstract}

Abstract

Key words: Impact; Juvenile delinquency; Awareness 


\section{PENDAHULUAN}

Masa remaja merupakan masa pencarian jati diri untuk menentukan jalan kehidupannya. Remaja dapat dikatakan sebagai masa peralihan dari anak-anak menuju dewasa. Seorang remaja sudah tidak lagi dapat dikatakan sebagai kanak-kanak, namun masih belum cukup matang untuk dapat dikatakan dewasa. Pada dasarnya seorang remaja yang sedang melakukan pencarian jati diri, jika dihadapkan pada keadaan lingkungan yang penuh kontradiksi dan labil, maka hal tersebut akan membuat remaja terperangkap pada ketidakpastian. Para remaja biasanya ingin menunjukkan eksistensi diri dengan caranya sendiri.

Dalam menentukan jalan hidupnya kerap kali para remaja melalui kesalahan dalam melangkah, sehingga tidak menyadari bahwa perbuatan yang dilakukan justru bertentangan dengan aturan nilai dan norma di dalam kehidupan masyarakat, salah satu perbuatan yang dilakukan adalah melakukan kenakalan. Menurut Kartono (2010: 6) Kenakalan remaja dikenal dengan istilah Juvenile delinquency yaitu perilaku yang jahat (dursila) kenakalan anak-anak muda, keadaan patalogis pada remaja yang disebabkan bentuk pengabaian sosial, sehingga mengembangkan kearah perilaku menyimpang. Sedangkan menurut Priyanto (2015) kenakalan remaja diartikan sebagai perbuatan kejahatan yang dilakukan anak remaja, perbuatan tersebut dapat dikenakan sanksi pidana bagi remaja yang melanggar larangan tersebut.

Usia remaja dikatakan sebagai usia yang paling rentan melakukan kenakalan. Kategori usia remaja menurut Kartono (2019) jika berusia dibawah 21 tahun. Lebih rinci dijelaskan oleh Priyanto (2015: 6.39) batas usia remaja antara usia 10-20 tahun, dengan kategori usia remaja awal 10-14 tahun sedangkan remaja akhir 15-20 tahun. Remaja pada umumnya memiliki jiwa yang masih labil dan belum mempunyai pedoman yang kuat sehigga rentan berbuat nakal.

Di Indonesia masalah kenakalan remaja cukup memprihatinkan bagi masyarakat. Dilansir dari Komisi Perlindungan Anak Indonesia (2019) sepanjang bulan Januari sampai April 2019 sebanyak 37 kasus kekerasan diberbagai jenjang pendidikan. Masalah lainnya sering kali dilakukan remaja melakukan tauran pelajar, sebagaimana yang diungkapkan data Komisi Perlindungan Anak Indonesia (2019) angka tauran pelajar di Indonesia kian meningkat datanya dari tahun ke tahun, pada tahun 2017 sebesar 12,9 naik menjadi 14 persen di tahun 2018 .

Akhir-akhir ini banyak masalah yang menimbulkan keresahan masyarakat 
dilakukan oleh para remaja. Dari tindakan ringan sampai pada kekerasan. Beberapa contoh perilaku yang menimbulkan keprihatinan seperti bolos sekolah, tindakan yang sekedar mengganggu (arak-arakan sepeda motor), geng, pencurian, menonton video porno, pelecehan seksual, penyalahgunaan narkoba, bahkan melakukan pembunuhan.

Banyak pihak telah melakukan analisis dan kajian mengenai masalah tersebut untuk menemukan penyebab maupun upaya penanggulangannya. Namun, walau sudah banyak yang melakukan analisa tentang upaya pencegahan maupun penanggulannya, kesadaran remaja atas dampak perbuatan kenakalan remaja pun belum sepenuhnya mengena kedalam hati para remaja. Maraknya kenakalan remaja menunjukkan bahwa memang harus ada cara khusus untuk menyadarkan remaja akan dampak negatif dari kenakalan tersebut.

Kebanyakan dari remaja belum menyadari sepenuhnya akan dampak kenakalan yang dilakukan bukan hanya merusak diri sendiri bahkan juga merugikan orang lain atas perbuatannya. Remaja yang melakukan perbuatan kenakalan, maka waktu remajanya akan terbuang sia-sia sehingga dapat menghambat dirinya dalam meraih cita-cita di masa depan. Para remaja hanya ingin memenuhi kesenangan sesaat tanpa berpikir panjang efek kedepannya terutama untuk masa depan mereka.

Perilaku kenakalan remaja dapat terjadi dimana saja, termasuk remaja di Pulau Untung Jawa. Oleh karena itu, perlu adanya upaya untuk memberikan kesadaran tentang dampak kenakalan remaja terhadap masa depan dirinya, salah satunya dengan melakukan pengabdian kepada masyarakat yang berjudul: "Penyuluhan Dampak Kenakalan Remaja Untuk Meningkatkan Kesadaran Dari Bahaya Kenakalan Remaja Bagi Masa Depan”.

Tujuan pengabdian masyarakat ini berupaya untuk meningkatkan kesadaran remaja terhadap bahaya kenakalan remaja sehingga remaja dapat melakukan pencegahan agar tidak melakukannya. Kegiatan pengabdian ini sangat bermanfaat untuk masyarakat khususnya bagi remaja di Pulau Untung Jawa.

\section{METODE}

Metode kegiatan pengabdian masyarakat yaitu dengan cara memberikan penyuluhan atau melakukan ekspositori dengan memberikan sosialisasi berupa penyampaian materi secara verbal dengan pendekatan sosial.

Kegiatan pengabdian kepada masyarakat dilakukan di Pulau Untung Jawa Kepulauan Seribu Jakarta. Target sasaran 
pengabdian kepada masyarakat adalah remaja di Pulau Untung Jawa yang berjumlah 25 orang. Pada bulan Agustus sampai September 2019.

Prosedur dalam kegiatan ini dengan memberikan sosialisasi tentang dampak kenakalan remaja, kemudian sesi tanya jawab, dan sesi wawancara. Kegiatan lebih rinci tertuang dalam tabel di bawah ini:

\section{Tabel 1}

\section{Rincian Kegiatan Pegabdian Kepada \\ Masyarakat}

\begin{tabular}{llr}
\hline \multicolumn{1}{c}{ Metode } & \multicolumn{2}{c}{ Partisipasi } \\
\hline Ceramah & Peserta mendengarkan \\
& materi yang disampaikan \\
& oleh narasumber tentang \\
& kenakalan remaja. \\
\hline Tanya jawab & Peserta diberikan \\
& kesempatan untuk bertanya \\
& dan berdiskusi dengan \\
& permasalahan mengenai \\
& materi. \\
\hline Wawancara & Sesi \\
& dilaksanakan \\
& mengetahui sejauh mana \\
& tingkat kesadaran peserta \\
& untuk mengantisipasi \\
& bahaya kenakalan remaja.
\end{tabular}

Sumber: data penulis, 2019

\section{HASIL DAN PEMBAHASAN}

Kegiatan pengabdian kepada masyarakat yang dilakukan berjalan dengan lancar dari tahap perencanaan, pelaksanaan, sampai evaluasi. Langkah-langkah yang dilakukan untuk menunjang keberlangsungan acara di awali dengan tahapan perencanaan, yaitu melaksanakan observasi pendahuluan ke Pulau Untung Jawa untuk mencari permasalahan yang muncul dalam kehidupan sosial masyarakat. Mengidentifikasi apa saja yang menjadi keresahan masyarakat sekitar dan perlu diberikan pemahaman lebih tentang solusi permasalahan tersebut. Identifikasi masalah dilaksanakan dengan cara wawancara dengan masyarakat sekitar Pulau Untung Jawa. Setelah mendapatkan permasalahan yang didapatkan dari hasil wawancara dengan para masyarakat bahwa masih terdapat perilaku-perilaku remaja sekitar seperti bolos sekolah, mengganggu masyarakat sekitar, merokok, dan sebagainya. Oleh karena itu, perlu adanya penyuluhan tentang kenakalan remaja.

Langkah selanjutnya melakukan pembentukan Tim dosen pengabdian masyarakat, menentukan perencanaan waktu, serta pengurusan perizinan tempat pengabdian kepada masyarakat. 
Adapun rincian kegiatan digambarkan dalam tabel berikut ini :

Tabel 2

Tahapan Perencanaan Pengabdian

Masyarakat

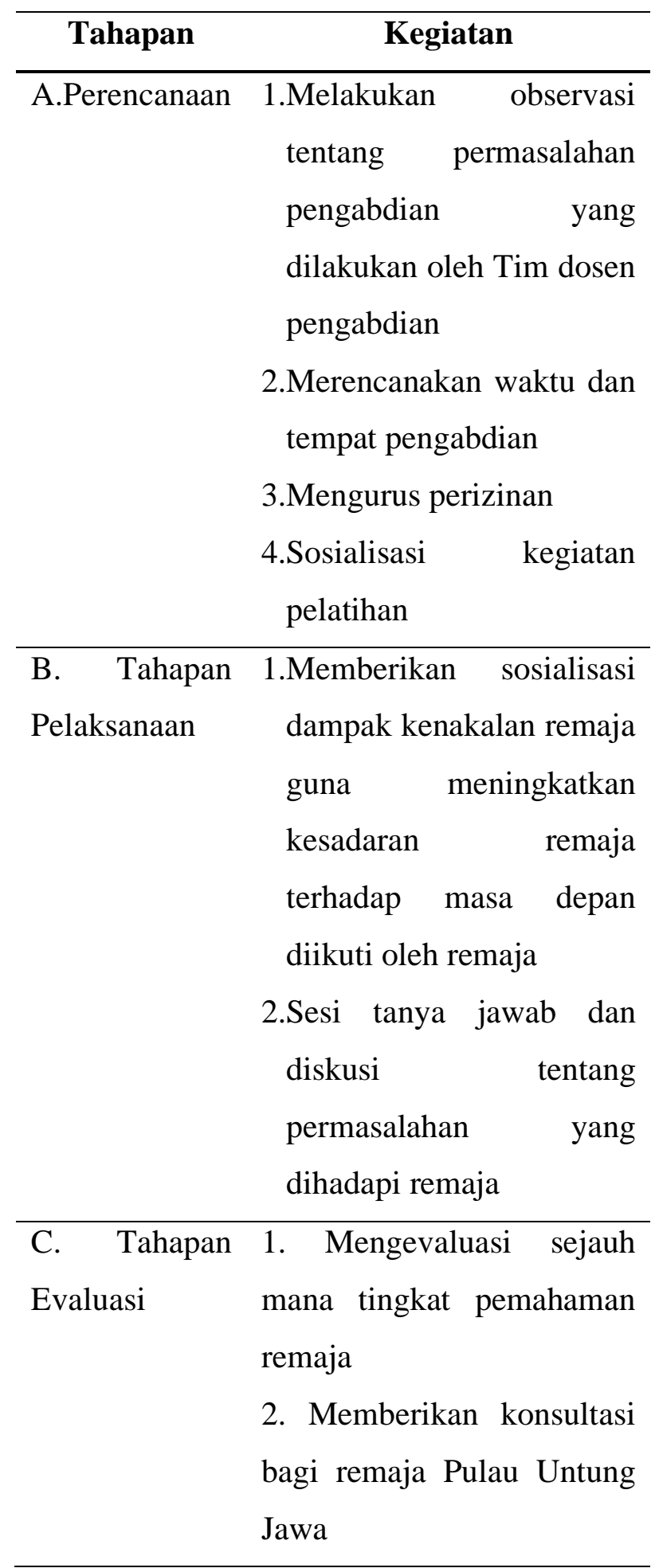

3. Melakukan tindak lanjut dari kegiatan pengabdian masyarakat

\section{Sumber: data penulis, 2019}

Pada tahapan pelaksanaan dilakukan kegiatan sosialisasi tentang dampak kenakalan remaja guna meningkatkan kesadaran remaja terhadap masa depannya. Kegiatan diawali dengan pembukaan kemudian dilanjutkan sambutan. Sambutan pertama disampaikan oleh ketua pelaksana pengabdian dan dilanjutkan dengan sambutan dari pihak Kelurahan Pulau Untung Jawa yakni bapak Supriyadi., S.Ip. beliau menyampaikan bahwa kegiatan pengabdian masyarakat yang dilaksanakan bisa memberikan dampak positif dan menambah pengetahuan bagi masyarakat yang diberikan penyuluhan. Selain itu, beliau berharap agar bisa berkelanjutan dalam memberikan penyuluhan atau sosialisasi dalam bentuk apapun untuk masyarakatnya.

Setelah sambutan langsung memasuki acara inti yakni pemberian materi sosialisasi. Materi disampaikan oleh tim dosen pengabdi. Materi tersebut dikemas dan disampaikan dengan rinci agar bisa diterima dengan baik oleh peserta. Materi yang disajikan diawali dari tanya jawab seputar pengertian kenakalan remaja dan diselingi dengan games. 
Kenakalan remaja atau Jevenile Delinquency. Kata juvenile yang berasal dari bahasa latin yakni ciri karakteristik dari anak-anak. Sedangkan Delinquency merupakan mengabaikan atau terabaikan. Namun secara umum pengertian kenakalan remaja mengandung arti suatu pelanggaran yang dilakukan oleh remaja. Pelanggaran yang dimaksud bermacam-macam dari yang bersifat merugikan diri sendiri bahkan orang lain.

Macam-macam kenakalan remaja yang dijelaskan sebagai berikut :

1. Mencoret coret dinding sekolah

2. Mencuri

3. Bolos

4. Merusak fasilitas sekolah

5. Perbuatan kekerasan

6. Anak-anak durhaka

7. Minum minuman beralkohol

8. Menggunakan narkotika

9. Mencontek waktu ulangan,

10. Pacaran

\section{Mengucapkan perkataan kotor}

Dari macam-macam kenakalan remaja yang terjadi disebabkan oleh beberapa faktor. Pemateri menjelaskan faktor kenakalan remaja: pertama, kejahatan dipelajari artinya tindak kejahatan dipelajari oleh pelakunya. Secara tidak langsung remaja akan mempelajari tindakan pencurian yang dilihat. Kedua, zona atau wilayah, artinya wilayah tempat tinggal remaja atau lingkungan pergaulan juga mempengaruhi terjadinya sebuah tindakan yang mengarah kepada kenakalan remaja. Ketiga, hidup tanpa norma, seseorang yang hidup tanpa norma akan melakukan hal apapun sesuka hatinya tanpa melihat hal itu membahayakan dirinya atau orang lain. keempat, mengadopsi budaya modern yang negatif.

Terdapat faktor-faktor yang mempengaruhi remaja berbuat kenakalan. Menurut Prasasti (2017) faktor penyebab terjadi kenakalan remaja meliputi faktor internal dan eksternal, faktor internal berasal dalam diri remaja keliru dalam menginternalisasikan diri sehingga tidak dapat menyelesaikan masalah, sedangkan faktor eksternal bersumber dari luar remaja meliputi masalah di lingkungan keluarga, sekolah, dan masyarakat.

Selain itu disampaikan pula bagaimana cara menanggulangi kenakalan pada remaja secara rinci yaitu:

1. Penguatan struktur/ peran keluarga

2. Penguatan Pendidikan

3. Penguatan Kelompok Dominan (peer group)

4. Penguatan Ikatan (bons) nilai (agama, adat, hukum)

5. Penguatan banteng (containment) diri (luar/ dalam).

Materi disampaikan dengan rinci dan menarik sehingga para peserta dengan antusias mendengarkan materi yang 
disampaikan. Selain itu pemateri menjelaskan beberapa kasus akibat dari kenakalan remaja dari yang kehilangan kepercayaan sampai pada kehilangan nyawa. Semua peserta meyadari akan bahaya tersebut yang akan berdampak pada masa depannya.

Tahap ketiga evaluasi, yakni untuk melihat sejauh mana peningkatan kesadaran remaja tentang dampak kenakalan remaja yang dapat merusak masa depan. Dari hasil tanya jawab menunjukkan bahwa remaja menyadari akan bahaya kenakalan remaja yang akan merusak masa depan dan mengecewakan orang tua. Serta peserta menyadari bahwa banyak penyebab remaja terjerumus kedalam kenakalan remaja salah satunya faktor internal dan eksternal.

Dalam pelaksanaan pengabdian masyarakat ini, para peserta pengabdian sangat antusias dalam melakukan konsultasi terhadap masalah yang ada dalam dirinya sehingga dengan adanya keterbukaan membuat remaja dapat melewati permasalahan dalam dirinya tanpa melakukan perilaku menyimpang yang dapat merusak dirinya. Terdapat peserta yang menceritakan tentang permasalahan tentang keluarga. Berikut gambar 1 dan 2 dokumentasi kegiatan pengabdian kepada masyarakat.

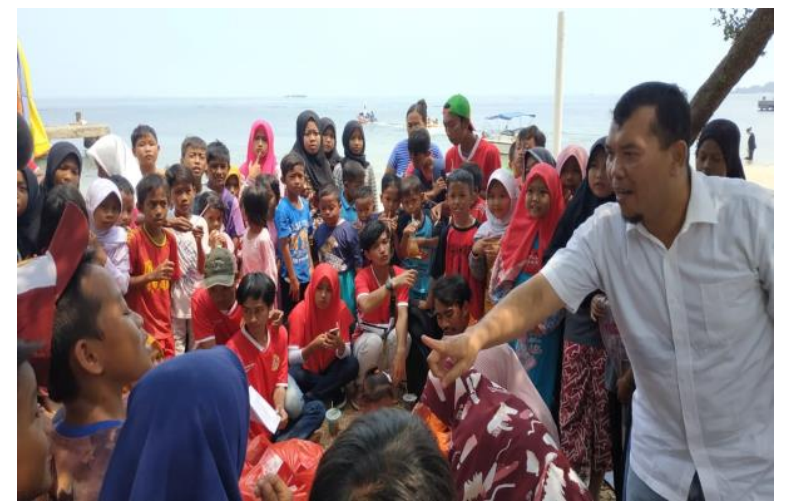

Sumber: Dokumentasi Penulis, 2019

Gambar 1

Interaksi dengan pemateri

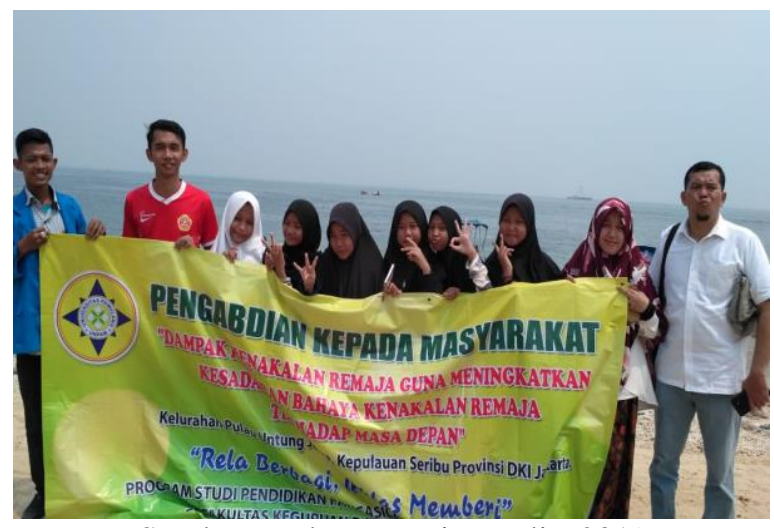

Sumber: Dokumentasi Penulis, 2019

Gambar 2

Penutupan dipinggir Pantai Pulau Untung Jawa

Dalam permasalahan yang dibahas dalam kegiatan pengabdian masyarakat ini maka ditemukan akar permasalahan adalah peran penting keluarga. Keluarga merupakan lembaga pertama yang dapat menjadikan anak-anak menjadi pribadi yang sesuai harapan orangtua bersumber pada nilai-nilai dan norma. Permasalahan dalam lembaga keluarga kerap kali mendatangkan permasalahan bagi anak termasuk terjerumus 
kedalam perbuatan nakal. Oleh karena itu, membentuk keluarga yang harmonis dalam menjalankan peran dan fungsi anggota keluarga sangat penting menangkal anak melakukan hal-hal yang negatif. Selain itu, orangtua memiliki peran yang sangat penting melakukan pengawasan dan perhatian saat anak beranjak remaja. Pengabdian masyarakat pernah dilakukan oleh Wardani (2018) melalui kegiatan penyuluhan psikoedukasi keluarga menjadikan orangtua lebih memahami tentang kenakalan remaja sehingga orangtua tidak hanya memberikan perhatian secara fisik, namun juga psikologis dan sosial. Selaras dengan hasil pengabdian masyarakat yang dilakukan Nursyifa (2019) bahwa peran penting keluarga dalam upaya pencegahan dampak negatif teknologi yang berujung pada perilaku menyimpang yang dilakukan anak. Berdasarkan hasil pengabdian tersebut maka keluarga memiliki peran sangat penting agar anak tidak melakukan perilaku menyimpang. Oleh karena itu, penerapan pola asuh yang disesuaikan dengan tuntutan zaman dan menerapkan keterbukaan kepada orang tua sangat penting mendidik anak agar tidak terjerumus dalam perilaku kenakalan remaja.

Selain itu, upaya pencegahan kenakalan remaja perlu dilakukan dengan menjalin kerjasama semua pihak untuk mencegah masalah kenakalan remaja meliputi: orangtua, sekolah, dan masyarakat.
Sebagaimana yang diungkapkan Unayah (2015) orangtua, sekolah, masyarakat, tokoh masyarakat, serta penegak hukum yang berperan dalam menanggulangi masalah kenakalan remaja.

Pengabdian kepada masyarakat yang dilakukan tentang kenakalan remaja pernah dilakukan Supriyadi (2019) penyuluhan kenakalan remaja kepada orangtua terbukti dapat mengurangi jumlah kenakalan remaja. Selaras dengan hasil pengabdian yang dilakukan Hidayat (2018) melakukan penyuluhan tentang pentingnya peran keluarga, guru, dan masyarakat menjadi pondasi dalam membentengi dari perilaku kenakalan remaja. Hasil pengabdian masyarakat yang dilakukan Na'mah (2019) kegiatan pengabdian masyarakat terbukti dapat meningkatkan pengetahuan tentang kenakalan remaja. Selaras dengan Yuhandra (2018) hasil pengabdian masyarakat diperoleh masyarakat lebih peka terhadap masalah kenakalan remaja, sehingga orangtua yang memiliki anak remaja lebih memperhatikan serta mengawasi anaknya yang beranjak remaja.

Berdasarkan hasil pengabdian kepada masyarakat tersebut, dapat disimpulkan bahwa penyuluhan tentang bahaya kenakalan remaja sangat penting dilakukan sebagai solusi dari pemecahan masalah kenakalan remaja di masyarakat, sehingga dengan adanya penyuluhan sebagai upaya preventif 
yang cukup efektif dalam mencegah perilaku kenakalan yang dilakukan remaja.

Kelemahan dalam kegiatan ini yakni sebagian peserta belum menyadari akan dampak kenakalan remaja terhadap masa depan, mereka beranggapan jenis perilaku yang dilakukan hanya memberikan dampak negatif yang tidak terlalu besar. Oleh karena itu, perlu adanya program tindak lanjut dari kegiatan pengabdian kepada masyarakat selanjutnya tentang bahaya kenakalan remaja. Remaja dapat diarahkan kepada kegiatan positif di masyarakat misalnya dengan pendekatan agama, mengenyam pendidikan, aktif di karang taruna, mengikuti berbagai aktivitas olahraga, kesenian, dan sebagainya.

\section{KESIMPULAN}

Kegiatan pengabdian kepada masyarakat berjalan dengan lancar sesuai dengan perencanaan awal sampai akhir kegiatan. Semua peserta semangat dan sangat antusias mengikutinya. Ditambah dengan diskusi dan tanya jawab antara peserta dan pemateri, para peserta melakukan konsultasi untuk membahas permasalahan yang mereka hadapi.

Kegiatan pengabdian ini memberikan manfaat tidak hanya bagi Universitas Pamulang tetapi juga bagi remaja pulau
Untung Jawa Kepulauan Seribu. Kegiatan pengabdian ini diharapkan dapat dilaksanakan secara berkelanjutan dan memberikan pemahaman yang lebih lagi bagi para remaja.

\section{UCAPAN TERIMAKASIH}

Terimakasih kami ucapkan untuk Yayasan Universitas Pamulang dan para dosen Prodi PPKn Universitas Pamulang atas dukungan baik secara materil maupun moril, Terimakasih pula untuk kelurahan Pulau Untung Jawa yang telah mengizinkan dan menyiapkan tempat pelaksanaan penyuluhan ini sehingga kegiatan pengabdian kepada masyarakat berjalan dengan lancar.

\section{REFERENSI}

Detik. (2019). Angka Kekerasan Pada Anak Bulan Januari- April 2019 Masih Tinggi. Diakses pada https://news.detik.com/berita/d4532 984/kpa'angka-kekerasan. Pada 1 September 2019.

Hidayat, S., \& Reza, A. (2018). Peningkatan Kualitas Pemberdayaan Guru dan Masyarakat Untuk Meminimalisir Terjadinya Kenakalan Remaja di Desa Ciasihan. Abdi Dosen: Jurnal Pengabdian Pada Masyarakat, 2(3). 
Kartono, K. (2010). Kenakalan Remaja. Jakarta: Rajawali Pers.

Na'mah, L. U., Zakiyyah, N., Khasanah, E. W., Hermawan, H., \& Setiawan, A. (2019). Peningkatan Pengetahuan Melalui Sosialisasi Kesehatan Reproduksi Remaja tentang Kenakalan Remaja. Proceeding of The URECOL, 263-266.

Nursyifa, A. (2019). The Socialization of the Important of Family Roles as Prevention Actions toward the Negative Impact of Technology on Children in the Digital Age [Sosialisasi Peran Penting Keluarga Sebagai Upaya Pencegahan Dampak Negatif Teknologi pada Anak dalam

Era Digital]. Proceeding of Community Development, 2, 648-657.

Prasasti, S. (2017). Kenakalan remaja dan faktor penyebabnya. In Prosiding Seminar Nasional Bimbingan dan Konseling (Vol. 1, No. 1, pp. 2845).

Priyanto, A \& Soenarjati. (2015). Kriminologi dan Kenakalan Remaja. Tangerang Selatan: Universitas Terbuka.
Supriyadi, I. (2019). Sosialisasi Kenakalan Remaja Milenial. Majalah Ilmiah" PELITA ILMU", 2(2).

Tribunnews. (2019). Angka Tauran Meningkat dari Tahun ke Tahun. Diakses pada https://surabaya.tribunnews.com/20 19/09/22/angka-tawuran-meningkat. Pada 22 September 2019.

Unayah, N., \& Sabarisman, M. (2016). Fenomena kenakalan remaja dan kriminalitas. Sosio informa, 1(2).

Wardani, L. K., Ratih, N., Soares, R. J., Irmastuti, V. R., \& Ridzal, S. (2018). Pengenalan dan Pencegahan Kenakalan Remaja (Adult Delicuency) melalui Psikoedukasi Keluarga. Journal of Community Engagement in Health, 1(1), 4-6.

Yuhandra, E. (2018). Pencegahan dan Penindakan Kenakalan Remaja pada Era Informatika di Kabupaten Kuningan, Indonesia. Empowerment: Jurnal Pengabdian Masyarakat, $1(01)$. 